\title{
Molecular Rearrangements of the MLL Gene Are Present in Most Cases of Infant Acute Myeloid Leukemia and Are Strongly Correlated with Monocytic or Myelomonocytic. Phenotypes
}

\author{
Poul H. B. Sorensen, * Chien-Shing Chen, ${ }^{\star}$ Franklin O. Smith, ${ }^{\star 1}$ Diane C. Arthur, ${ }^{\star 1}$ Peter H. Domer, ${ }^{5}$ Irwin D. Bernstein, ${ }^{\star}$ \\ Stanley J. Korsmeyer, ${ }^{3}$ G. Denman Hammond,"' and John H. Kersey *1 \\ * Departments of Laboratory Medicine/Pathology and Pediatrics, and Bone Marrow Transplantation Program, University of Minnesota, \\ Minneapolis, Minnesota 55455; ${ }^{\ddagger}$ Department of Pediatric Hematology-Oncology, the Fred Hutchinson Cancer Research Center, Seattle, \\ Washington 98104; ${ }^{\S}$ Howard Hughes Medical Institute, Washington University School of Medicine, St. Louis, Missouri 63110; \\ "Department of Pediatrics, University of Southern California School of Medicine, Los Angeles, California 90033; and 'Childrens Cancer \\ Group, Arcadia, California 91006
}

\begin{abstract}
Cytogenetic studies have previously identified abnormalities of chromosome band 11q23 in many cases of infant acute leukemia. Recent studies by ourselves and others have demonstrated breakpoint clustering in acute leukemias bearing translocations involving 11q23, and a Drosophila trithorax gene homologue (called $M L L, H R X$, or $A L L-1$ ) has been shown to span the 11 q23 breakpoints of these translocations. To determine if this gene is affected in infant acute myeloid leukemia (AML), we have analyzed 26 infant AML cases for molecular alterations of this 11 q 23 gene. 15 out of 26 cases studied (58\%) showed rearrangement of the $M L L$ gene at the molecular level, and these rearrangements were clustered within an $\sim 11-\mathrm{kb}$ region containing nine exons of this gene. Moreover, 14 of the 15 cases with 11q23 rearrangements (93\%) had myelomonocytic or monocytic phenotypes (M4 or M5 FAB subtypes, respectively), both of which are associated with a poor prognosis in childhood AML. In contrast, only 1 of 11 nonrearranged cases had an M4 or M5 phenotype $(P=0.00002)$. Rearrangement also correlated significantly with hyperleukocytosis ( $P$ $=0.02$ ), another clinical parameter associated with poor outcome in this disease. Our results demonstrate that molecular rearrangements of $M L L$ are common in M4 or M5 infant $A M L$, and suggest that alteration of this gene may result in abnormal control of proliferation and differentiation in monocytic progenitor cells. (J. Clin. Invest. 1994. 93:429-437.) Key words: chromosome band 11 q 23 - infant leukemia • acute myeloid leukemia • molecular genetics • M4/M5 phenotype
\end{abstract}

Address correspondence to Dr. John H. Kersey, Box 86, UMHC, University of Minnesota, 420 Delaware Street S.E., Minneapolis, MN 55455. Dr. Poul H. B. Sorensen's present address is British Columbia's Children's Hospital, 4480 Oak Street, Vancouver, British Columbia, Canada, V6H 3 V4. 1993

Received for publication 2 April 1993 and in revised form 5 October

J. Clin. Invest.

(c) The American Society for Clinical Investigation, Inc.

0021-9738/94/01/0429/09 \$2.00

Volume 93, January 1994, 429-437

\section{Introduction}

Acute myeloid leukemia (AML) ${ }^{1}$ occurring in infants shows several important clinical differences when compared with AML in older children. First, AML is more prevalent among infants than older children, where lymphoblastic forms are much more common. In fact, AML is the most common form of acute leukemia occurring congenitally or within the first 4 wk of life (1). Second, infant AML shows a higher incidence of myelomonocytic or monocytic phenotypes (M4 and M5 French-American-British [FAB] subtypes, respectively) $(2,3)$. Third, AML in infants is more commonly associated with hyperleukocytosis and extramedullary disease $(4,5)$. Finally, cytogenetic studies have identified abnormalities of chromosome band $11 \mathrm{q} 23$ in up to $45 \%$ of infant AML patients, while this finding is less frequent in older age groups $(2,3,6)$. These observations suggest that AML in infants may be biologically distinct from that occurring in older children.

Mechanisms of leukemogenesis in childhood acute leukemia remain largely unknown. The high incidence of cytogenetic abnormalities of $11 \mathrm{q} 23$ in infant cases suggests that this region may be critically important in infant acute leukemia. Nonrandom translocations or interstitial deletions involving band $11 \mathrm{q} 23$ have previously been observed at the cytogenetic level in acute leukemia. Chromosomal bands involved in these translocations include $1 \mathrm{q} 21,2 \mathrm{p} 21,6 \mathrm{q} 27,9 \mathrm{p} 22,10 \mathrm{p} 11,17 \mathrm{q} 25$, and 19p13 in AML (especially M4 and M5 subtypes), and $1 \mathrm{p} 32,4 \mathrm{q} 21$, and $19 \mathrm{p} 13$ in acute lymphoblastic leukemia (ALL) $(7,8)$. Similar translocations have also been observed in AML secondary to therapy with epipodophyllotoxins for the treatment of ALL (9-11). At the molecular level, we (12) and others (13-15) have previously reported breakpoint clustering in acute leukemia cell lines or patients with $11 \mathrm{q} 23$ translocations. Moreover, transcriptional units spanning the $11 \mathrm{q} 23$ breakpoint region of cell lines with translocations involving chromosomal band $11 \mathrm{q} 23$ have been detected using probes from this region $(13,16)$. Recently, the cloning and sequencing of cDNA species from tumor cells with the $t(4 ; 11)$,

1. Abbreviations used in this paper: ALL, acute lymphoblastic leukemia; AML, acute myeloid leukemia; CCG, Childrens Cancer Group; FAB, French-American-British; HRX, human trithorax; MLL, myeloid/lymphoid leukemia. 
$\mathrm{t}(11 ; 19)$, or $\mathrm{t}(9 ; 11)$ indicate that the same gene from $11 \mathrm{q} 23$ is disrupted by these translocations (17-20). Sequence analysis of the 11q23 gene reveals potential zinc finger DNA binding motifs as well as DNA binding adenosine-thymidine (AT) hook motifs related to those of high mobility group proteins in the gene product $(17-19)$. This gene has been given several names, including myeloid/lymphoid leukemia ( $M L L)$ (13), acute lymphocytic leukemia-1 ( $A L L-1)$ (19), and human trithorax $(H R X)(18)$, the latter in view of significant homology of the human gene with the trithorax homeobox gene of drosophila (17-19). Fusion transcripts from the $t(4 ; 11)$, $t(11 ; 19)$, and $t(9 ; 11)$ code for chimeric proteins containing the AT hook DNA binding motifs of the $11 \mathrm{q} 23$ gene product fused to previously undescribed proteins encoded for by genes located on the respective partner chromosomes (18-20). To begin to analyze the clinical significance of alterations of the $M L L$ gene, we have previously analyzed a series of infant ALL cases for molecular rearrangements of this locus, given the high incidence of cytogenetic abnormalities of band 11 q 23 in infant acute leukemia. In this prior study we found molecular rearrangements of the 11 q23 gene in 21 of $30(70 \%)$ infant ALL cases (21). In fact, these alterations correlated with a significantly worse prognosis, and absence of rearrangement identified a group of infant ALL patients with a very good prognosis. Therefore, alteration of this gene may be involved in the pathogenesis of ALL in infants.

To confirm that $M L L$ is also altered in infant AML, we have now performed Southern blot analysis of clinical samples from a series of infant AML cases using probes derived from this locus. Our findings indicate that molecular rearrangements of $M L L$ are indeed common in infant AML, and that these rearrangements map to the same region altered in infant ALL. Furthermore, rearrangements of this gene in infant AML are strongly correlated with monocytic or myelomonocytic phenotypes and with hyperleukocytosis, two parameters previously correlated with a poor prognosis in this disease.

\section{Methods}

Patients and cell lines. Bone marrow or peripheral blood specimens used in this study were obtained at the time of diagnosis from patients with AML. The selection of AML samples for this study was based only on patients being $\leq 1 \mathrm{yr}$ of age at the time of diagnosis and availability of cryopreserved samples for analysis. All cases were enrolled in and treated with several Childrens Cancer Group (CCG) protocols as indicated in Table I, except where noted. The specific CCG protocols have been detailed elsewhere $(22,23)$. The diagnoses of AML in the cases under study were made at contributing institutions and were based on standard FAB morphologic and cytochemical criteria. The diagnoses were confirmed by central CCG review. Clinical information on the study cases is included in Table I, including age at diagnosis, treatment protocol, FAB subtype, white blood cell count at diagnosis, whether or not CNS leukemia was present at diagnosis, whether or not remission was achieved, and the duration of first remission if achieved. Immunophenotyping was carried out by detection of cell surface antigens using a standard flow cytometric indirect immunofluorescence assay (24); this testing was performed at the CCG AML Reference Laboratory (Department of Pediatric Oncology, Fred Hutchinson Cancer Research Center, Seattle, WA). Methods for the immunotyping of samples have been previously described (24). Cell surface antigen expression in the study cases is presented in Table II. The RS4;11 cell line, an ALL cell line with the $t(4 ; 11)(q 21 ; q 23)$, has been previously characterized morphologically and cytogenetically (25). The B1 cell line, also an ALL line with the $t(4 ; 11)(q 21 ; q 23)$, was a generous gift from Dr.
MH Freeman (Sick Children's Hospital, Toronto, Ontario) (26). The T-ALL cell line, MT, has been previously described (27).

Cytogenetic studies. Cytogenetic analyses were done by CCG institutional laboratories using standard techniques. Cytogenetics reporting forms, including processing and analysis information as well as original karyotypes, were centrally reviewed by at least two members of the CCG Cytogenetics Committee in 11 cases. Institutional results were reviewed by the Committee Chairperson only (Dr. D. C. Arthur, University of Minnesota) in eight cases. The remaining seven cases were not available for review. Case analyses were accepted as adequate if an abnormal clone was defined or if 15 or more metaphase cells were analyzed and found to be karyotypically normal. Karyotypes were designated according to the International System for Human Cytogenetic Nomenclature (1991) (28).

Statistical analysis. Cases were classified according to molecular analysis into two groups, one positive for 11 q23 gene rearrangements and one negative for this finding. The two groups were compared with respect to various clinical and laboratory features using Fisher's exact test.

Molecular genetic studies. Probes used in this study are described elsewhere $(21,29)$. Briefly, p98.40 and ps4 are single copy genomic probes located centromerically and telomerically, respectively, to the RS4;11 derivative 11 chromosomal breakpoint. They were isolated from lambda subclones of a Washington University (St. Louis, MO) YAC clone containing the RS4;11 breakpoint. The $4.2 \mathrm{E}$ probe is a subclone of the germline EcoRI restriction fragment located adjacent and telomeric to the EcoRI fragment recognized by ps4. The positions of the three probes in a germline map of the $M L L$ locus are indicated in Fig. 2. DNA was isolated from clinical samples using a modified protocol optimizing recovery from samples with limited material (30). DNA isolated from RS4;11 or B1 cells was used as positive control DNA, and MT cell DNA was used as germline control DNA. Southern blot analysis was performed according to standard procedures using Nytran (Schleicher \& Schuell, Inc., Keene, NH) or Hybond-N filters (Amersham Corp., Arlington Heights, IL). Probes were labeled to high specific activity with $\left[{ }^{32} \mathrm{P}\right]$ deoxycytidine triphosphate (dCTP) using the random primer method (31). Membranes were stripped and tested for residual probe binding before hybridization with a different probe. Experiments using 4.2E required the inclusion of $400 \mu \mathrm{g} / \mathrm{ml}$ total human placental DNA (Sigma Chemical Co., St. Louis, MO) in the hybridization solution to preanneal repetitive sequences recognized by this probe.

\section{Results}

High frequency of molecular rearrangements of $M L L$ in infant $A M L$. We investigated 26 cases of infant AML (summarized in Table I) for molecular rearrangements of the $M L L-1$ gene by Southern blot analysis using p98.40, ps4, and 4.2E genomic probes. These probes are derived from a region containing exons 5-13 of this gene (19, 21, 29; see also Fig. 2$)$ and recognize the following germline fragments: $(a)$ p98.40: $13 \mathrm{~kb}$ (HindIII digests), $5.1 \mathrm{~kb}$ (EcoRI), and $15 \mathrm{~kb}$ (BamHI digests); (b) ps4: $13 \mathrm{~kb}$ (HindIII digests), $4.6 \mathrm{~kb}$ (EcoRI digests), and $8.5 \mathrm{~kb}$ (BamHI digests); (c) 4.2E: 13 and $2.2 \mathrm{~kb}$ (HindIII digests), $4.2 \mathrm{~kb}$ (EcoRI digests), and 15 and $8.5 \mathrm{~kb}$ (BamHI digests). As shown in Fig. 1, $a-e, 15$ of 26 infant AML cases $(58 \%)$ showed additional bands by Southern analysis using the above restriction enzymes and probes, indicating rearrangements of $M L L$. A summary of the results for all 26 infant AML cases studied is shown in Table III. As indicated, all rearranged cases showed alterations at $11 \mathrm{q} 23$ with at least two different restriction enzymes and at least two different probes. Moreover, a large number of negative control DNA samples did not show evidence of $11 \mathrm{q} 23$ gene rearrangements using the restriction enzymes and probes described in this study (data not 
Table I. Clinical Data of Infant AML Cases

\begin{tabular}{|c|c|c|c|c|c|c|c|c|}
\hline & Patient & $\begin{array}{l}\text { CCSG } \\
\text { protocol }\end{array}$ & $\begin{array}{c}\text { Age at } \\
\text { diagnosis }\end{array}$ & $\begin{array}{c}\text { FAB } \\
\text { subtype }\end{array}$ & WBC & $\begin{array}{c}\text { CNS } \\
\text { leukemia }\end{array}$ & $\begin{array}{l}\text { Remmission } \\
\text { achieved }\end{array}$ & $\begin{array}{l}\text { Duration of first } \\
\text { remission }\end{array}$ \\
\hline & & & mo & & $\times 10^{9} /$ liter & & & $m o$ \\
\hline \multirow{15}{*}{$\begin{array}{l}\text { Molecular } \\
\text { rearrangement } \\
\text { of } 11 \mathrm{q} 23\end{array}$} & 1 & 2861 & 1 & M5 & 467 & + & $\mathbf{N}$ & 0 \\
\hline & 2 & $213 P$ & 2 & M4 & 429 & - & $\mathbf{N}$ & 0 \\
\hline & 3 & 2891 & 2 & M4 & 90 & + & $\mathrm{Y}$ & 5 \\
\hline & 4 & 2891 & 3 & M2 & 29 & - & $Y$ & $9+$ \\
\hline & 5 & 2891 & 4 & M4 & 170 & - & $\mathrm{Y}$ & $1+$ \\
\hline & 6 & 2891 & 5 & M5 & 194 & - & $\mathrm{N}$ & 0 \\
\hline & 7 & 213 & 5 & M5 & 168 & + & $Y$ & 4 \\
\hline & 8 & 213 & 5 & M4 & 524 & + & $Y$ & 1 \\
\hline & 9 & NOS & 5 & M4 & 114 & - & $\mathrm{Y}$ & $4+$ \\
\hline & 10 & 213 & 6 & M4 & 63 & - & $\mathrm{Y}$ & $10+$ \\
\hline & 11 & 2891 & 9 & M5 & 177 & - & $\mathrm{Y}$ & $1+$ \\
\hline & 12 & 2891 & 9 & M5 & 68 & - & $\mathbf{Y}$ & $5+$ \\
\hline & 13 & 2861 & 10 & M4 & 35 & + & $Y$ & 3 \\
\hline & 14 & 2891 & 11 & M4 & 208 & - & $\mathbf{N}$ & 0 \\
\hline & 15 & 213 & 12 & M5 & 116 & + & $\mathrm{Y}$ & 6 \\
\hline \multirow{11}{*}{ Germline $11 \mathrm{q} 23$} & 16 & NOS & $4 \mathrm{~d}$ & M7 & 94 & ND & $\mathbf{N}$ & 0 \\
\hline & 17 & 2891 & 1 & M2 & 34 & - & $Y$ & $3+$ \\
\hline & 18 & 2891 & 4 & M1 & 47 & - & $\mathrm{Y}$ & 1 \\
\hline & 19 & 2891 & 6 & M1 & 124 & + & $\mathrm{N}$ & 0 \\
\hline & 20 & 2891 & 7 & M2 & 29 & - & $\mathrm{Y}$ & $1+$ \\
\hline & 21 & 2891 & 7 & M2 & 32 & + & $Y$ & 4 \\
\hline & 22 & 2891 & 7 & M1 & 34 & - & $\mathrm{N}$ & 0 \\
\hline & 23 & 213 & 7 & M3 & 55 & - & $\mathrm{N}$ & 0 \\
\hline & 24 & 213 & 7 & M5 & 416 & + & $\mathbf{N}$ & 0 \\
\hline & 25 & 2891 & 9 & M2 & 65 & - & $\mathbf{N}$ & 0 \\
\hline & 26 & 2891 & 12 & M6 & 9 & - & $\mathrm{Y}$ & 11 \\
\hline
\end{tabular}

NOS, not on study; ND, not determined. Germline 11 q23 indicates cases without detectable molecular rearrangements of $11 \mathrm{q} 23$.

shown). It is therefore highly unlikely that the observed alterations are the result of either germline RFLPs or partial digestion of DNA.

Mapping of 11q23 rearrangements in infant $A M L$. Fig. 2 shows a germline restriction map of the genomic region implicated in leukemia-associated molecular alterations of $M L L$, including the positions of the p98.40, ps4, and 4.2E probes as well as the published exon-intron structure of this region (19, 29). This map also shows the breakpoint positions of the RS4;11 (24) and $B_{1}(25) t(4 ; 11)$ ALL cell lines. We used restriction fragment data from Table III to map the 15 rearranged infant AML cases within this region. As shown in Fig. 2, five cases $(1,3,7,8$, and 13$)$ mapped to the centromeric BamHIEcoRI fragment in the figure based on the identification of rearrangements in EcoRI digests by $\mathrm{p} 98.40$ but not in BamHI digests using the same probe. Four cases $(6,10,11$, and 12) could be mapped to the region lying between the EcoRI site telomeric to p 98.40 and the $5^{\prime}$ end of the ps 4 probe. This was based on the detection of rearrangements in these cases using EcoRI and ps4, and the fact that ps4 and 4.2E detected identical fragments in HindIII digests as well as in BamHI digests (aside from case 12). Case 14 mapped to the region telomeric of ps 4 and centromeric to the EcoRI site at the $5^{\prime}$ end of $4.2 \mathrm{E}$ based on an EcoRI/ps4 rearrangement and identical rearranged HindIII/p98.40 and HindIII/ps4 bands. Cases 15 and 2 both mapped to the telomeric-most BamHI-EcoRI frag- ment in the figure based on the presence of EcoRI/4.2E rearrangements but germline BamHI/ps4 fragments. Case 15 was further mapped centromeric to the HindIII site in this region since identical HindIII/p98.40 and HindIII/ps4 fragments were detected while case 2 was located telomeric to the HindIII site since a HindIII/4.2E rearrangement was observed along with germline HindIII/p98.40 and HindIII/ps4 bands. Cases 4 and 9 both lacked detectable rearrangements in EcoRI digests, making mapping of these cases more difficult (see Discussion). They were both mapped to the same region as case 15 based on the presence of identical HindIII/p98.40 and HindIII/ps4 fragments, and rearrangements in BamHI digests were limited to the $4.2 \mathrm{E}$ probe. Finally, case 5 mapped to the telomeric-most EcoRI-HindIII fragment since only HindIII/4.2E or BamHI/ 4.2E rearrangements could be detected in this case. These findings therefore indicate that all 15 cases could be mapped to an $\sim 11-\mathrm{kb}$ region of the $11 \mathrm{q} 23$ gene encompassed by the centromeric BamHI site and the telomeric HindIII site of Fig. 2.

Molecular rearrangements of MLL in cases lacking cytogenetic abnormalities of 11q23. The results of cytogenetic studies are given in Table IV. Analyses were adequate in 17 of the 26 patients investigated by molecular studies. Abnormal clones were defined in $14(82 \%)$ of these 17 patients. Among the 15 patients with molecular rearrangements of $11 \mathrm{q} 23,11$ had adequate cytogenetic analyses available for central review. 10 (91\%) of these 11 cases demonstrated an abnormal clone and 7 
Table II. Immunophenotyping of Infant AML Cases

\begin{tabular}{|c|c|c|c|c|c|c|c|c|c|c|c|c|c|c|}
\hline & Patient & CD2 & CD3 & CD4 & CD5 & CD8 & CD10 & CD15 & CD19 & CD20 & CD33 & CD34 & CD36 & $\mathrm{CD} 42 \mathrm{~b}$ \\
\hline \multirow{15}{*}{$\begin{array}{l}\text { Molecular } \\
\text { rearrangement } \\
\text { of } 11 \mathrm{q} 23\end{array}$} & 1 & 6 & 8 & 30 & 10 & 3 & 2 & 64 & 6 & 19 & 85 & 0 & 65 & 8 \\
\hline & 2 & 2 & 3 & 79 & 4 & 2 & 3 & 94 & 4 & 4 & 91 & 0 & 50 & 1 \\
\hline & 3 & 2 & 0 & 46 & 0 & 1 & 1 & 90 & 0 & 0 & 92 & 0 & 35 & 23 \\
\hline & 4 & 8 & 6 & 28 & 10 & 4 & 2 & 78 & 6 & 4 & 78 & 0 & 26 & 18 \\
\hline & 5 & 5 & 3 & 5 & 4 & 2 & 6 & 44 & 20 & 3 & 83 & 18 & 46 & 20 \\
\hline & 6 & 4 & 3 & 88 & 4 & 2 & 0 & 90 & 1 & 5 & 88 & 0 & 1 & 0 \\
\hline & 7 & NA & NA & NA & NA & NA & NA & NA & NA & NA & NA & NA & NA & NA \\
\hline & 8 & 2 & 1 & 10 & 4 & 1 & 1 & 60 & 2 & 1 & 47 & 0 & 16 & 0 \\
\hline & 9 & 0 & 0 & 9 & 0 & 0 & 0 & 51 & 0 & 4 & 57 & 0 & 50 & 3 \\
\hline & 10 & 6 & 7 & 9 & 7 & 4 & 2 & 55 & 1 & 5 & 5 & 0 & 60 & 4 \\
\hline & 11 & 18 & 19 & 21 & 22 & 5 & 2 & 41 & 8 & 9 & 39 & 1 & 24 & 4 \\
\hline & 12 & 4 & 19 & 92 & 9 & 3 & 1 & 60 & 0 & 8 & 89 & 0 & 6 & 1 \\
\hline & 13 & 11 & 9 & 19 & 9 & 4 & 1 & 71 & 1 & 10 & 83 & 69 & 27 & 7 \\
\hline & 14 & 0 & 5 & 5 & 5 & 4 & 0 & 100 & 0 & ND & 100 & ND & ND & 4 \\
\hline & 15 & 9 & 12 & 89 & 14 & 5 & 1 & 72 & 3 & 6 & 81 & 0 & 24 & 3 \\
\hline \multirow[t]{11}{*}{ Germline $11 \mathrm{q} 23$} & 16 & ND & ND & ND & ND & ND & ND & ND & ND & ND & ND & ND & ND & ND \\
\hline & 17 & 0 & 0 & 1 & 0 & 0 & 0 & 0 & 21 & 0 & 87 & 83 & 1 & 71 \\
\hline & 18 & 1 & 0 & 0 & 0 & 0 & 0 & 14 & 0 & 0 & 80 & 38 & 27 & 13 \\
\hline & 19 & 4 & 0 & 87 & 3 & 0 & 0 & 4 & 0 & 0 & 90 & 79 & 3 & 0 \\
\hline & 20 & 7 & 5 & 7 & 3 & 4 & 1 & 15 & 0 & 0 & 89 & 63 & 23 & 8 \\
\hline & 21 & ND & 8 & ND & 38 & ND & 2 & ND & ND & 2 & 87 & ND & ND & ND \\
\hline & 22 & 19 & 16 & 64 & 18 & 7 & 2 & 42 & 9 & 17 & 21 & 0 & 24 & 1 \\
\hline & 23 & 4 & 1 & 5 & 3 & 2 & 0 & 3 & 6 & 1 & 92 & 87 & 1 & 84 \\
\hline & 24 & 1 & 2 & 16 & 2 & 1 & 0 & 87 & 1 & 6 & 91 & 0 & 1 & 0 \\
\hline & 25 & 30 & 0 & 24 & 0 & 0 & 0 & 14 & 0 & 0 & 80 & 38 & 27 & 13 \\
\hline & 26 & 30 & 14 & 31 & 31 & 11 & 21 & 8 & 18 & 19 & 13 & 0 & 51 & 16 \\
\hline
\end{tabular}

Data are percent of nucleated cells. NA, not available; ND, not determined.

of the 10 abnormal clones had breaks in band 11q23. Cytogenetic abnormalities of 11q23 included five balanced translocations with chromosomes $7,9,10,17$, and 19, one unbalanced translocation (der [11]), and one deletion. Of particular interest are the remaining four patients, three of whom (nos. 6, 7, and 10) had structural abnormalities of chromosome 11 involving breaks in bands other than 11q23, and one (no. 15) who was reported as having a normal karyotype. Among the 11 patients without molecular rearrangements of $11 \mathrm{q} 23,6$ had adequate cytogenetic analysis; 4 (67\%) of these had clonal chromosome abnormalities but none of these clones had cytogenetic rearrangements of $11 \mathrm{q} 23$. Of note is patient 26 , who had a break in band $11 \mathrm{p} 15$, as did patient 10 .

Molecular rearrangements of MLL correlate with monocytic or myelomonocytic phenotypes and with hyperleukocytosis. We next determined whether molecular rearrangements of $M L L$ were correlated with any of the clinical features summarized in Tables I or II. As shown in Table I, there was a striking association between $M L L$ alterations and myelomonocytic or monocytic phenotypes (M4 or M5 FAB subtypes, respectively), with 14 of 15 rearranged cases being either M4 or M5 subtypes (93\%) while only 1 of 11 nonrearranged cases was M4 or M5 $(P=0.00002)$. Moreover, of the 15 cases subtyped as M4 or M5 in this study, 14 (93\%) showed molecular rearrangement of this gene. In contrast, only 1 of the $11(9 \%)$ non-M4 or M5 cases was rearranged $(P=0.00002)$. The latter rearranged case (no. 4) had an M2 phenotype. Consistent with the monocytic/myelomonocytic phenotype seen morphologically is the strong expression of the CD15 antigen, which was observed in all analyzed cases with $M L L$ gene rearrangement (see Table II). In contrast, leukemias without rearrangements seldom showed CD15 expression.

Several other clinical features were also analyzed in this study. Hyperleukocytosis at the time of diagnosis (defined as a white blood cell count of $\geq 100 \times 10^{9}$ cells/liter) was noted in $67 \%$ of rearranged cases $(10 / 15)$, significantly higher than the $18 \%$ noted in cases with germline 1 lq23 $(2 / 11)(P=0.02)$. Age of $\leq 6$ mo at diagnosis was more common in rearranged cases $(10 / 15 ; 67 \%)$ compared with nonrearranged cases $(3 /$ $11 ; 27 \%)$ but this difference did not reach statistical significance $(P=0.11)$. Statistically significant immunophenotypic findings in this study (see Table II) included the high incidence of CD15 positivity in rearranged cases $(14 / 14 ; 100 \%)$ compared with relative absence of CD15 expression in nonrearranged cases $(2 / 9 ; 22 \%)(P<0.05)$. In addition, CD34 was expressed by the leukemic blasts in only $8 \%$ of the rearranged cases $(1 / 13)$ compared with $67 \%$ of the nonrearranged cases $(6 / 9)(P<0.05)$. The above morphological or clinical parameters were not influenced by the positions of the 1lq23 gene rearrangements as mapped by restriction enzyme analysis (see Fig. 2). There was no significant difference in whether remission was achieved when patients with or without leukemic blast cell rearrangements of the $M L L$ gene were compared. Further prognostic correlations could not presently be evaluated due to the short clinical follow up of most of the cases analyzed in this study. 

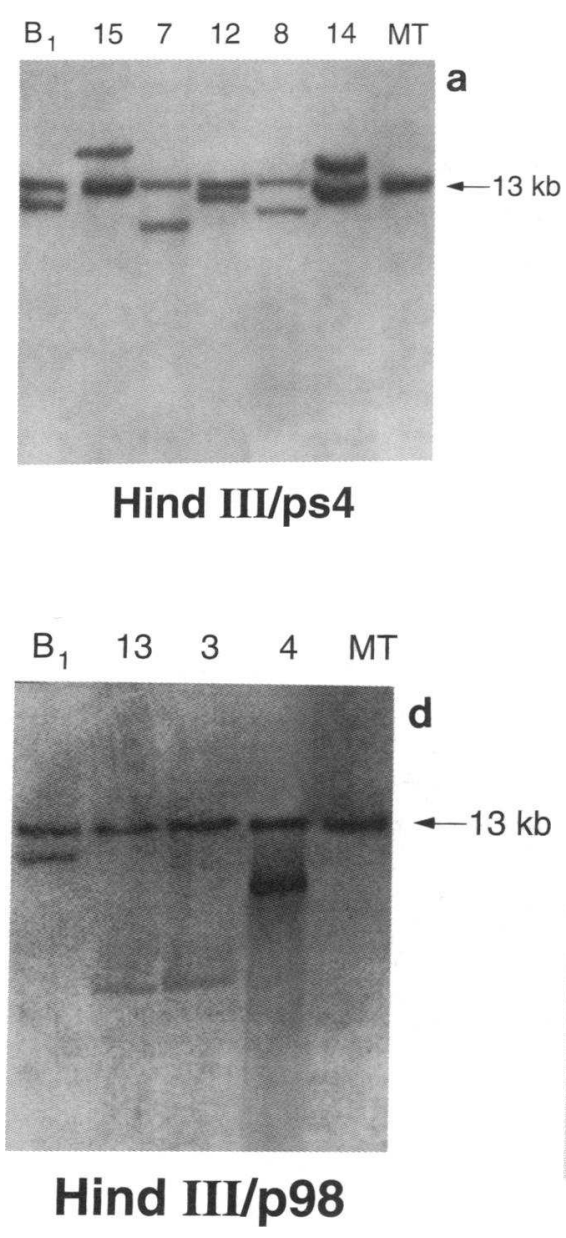
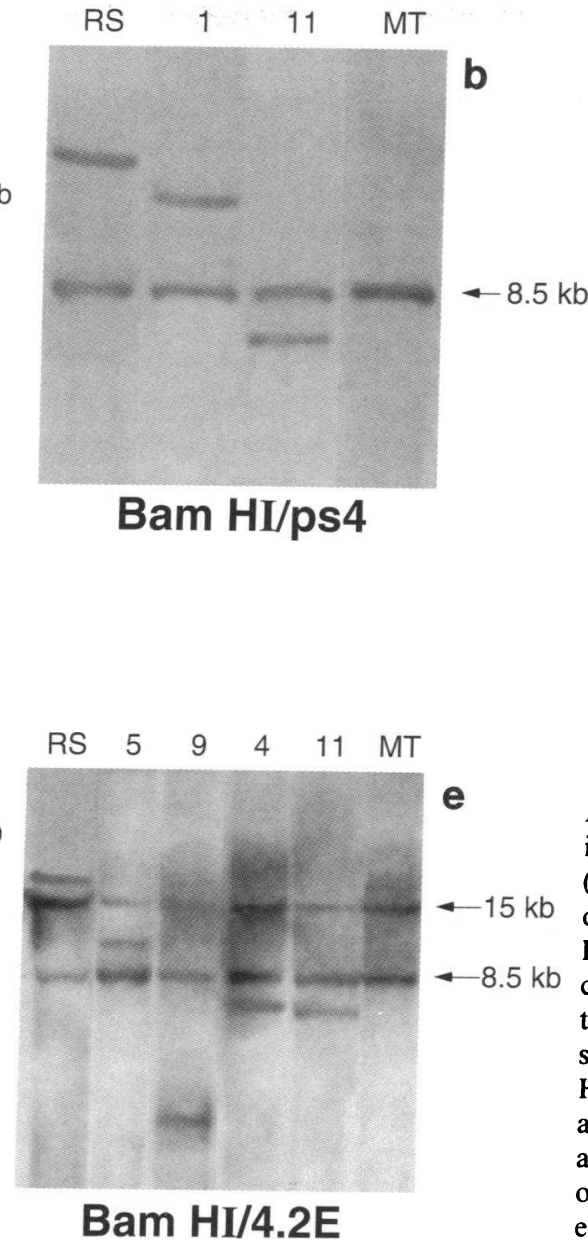

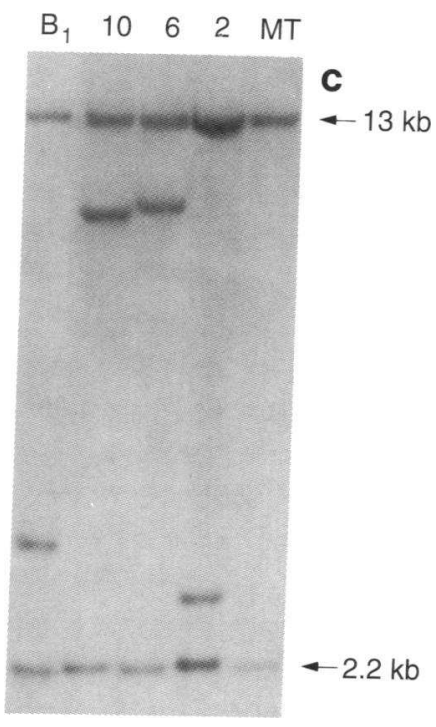

\section{Hind III/4.2 E}

Figure 1. Southern blot analysis of genomic DNA isolated from infant AML cases. The case numbers (see Table I) are indicated above the lanes. $10 \mu \mathrm{g}$ of DNA was loaded per lane. RS and $B_{1}$ refer to DNA isolated from RS4;11 and $B_{1}$ positive control cell lines, respectively. MT refers to DNA from the negative control T cell ALL cell line. The restriction enzymes and the probes used were: $(a)$ HindIII and ps4; $(b)$ BamHI and ps4; $(c)$ HindIII and 4.2E; $(d)$ HindIII and p98.40; and $(e)$ BamHI and 4.2E. Arrows indicate the positions and sizes of germline fragments for each set of restriction enzyme and probe.

\section{Discussion}

The acute leukemia-associated $t(4 ; 11), t(11 ; 19)$, and $t(9 ; 11)$ each result in the juxtaposition of sequences from the $M L L$ gene on chromosome band 11q23 to those of newly identified genes on the respective chromosome partners (17-20, 29). These gene fusions lead to the expression of chimeric transcripts and the formation of fusion products in tumor cells. The translocations are generally balanced but cytogenetic evidence suggests that the derivative 11 product may be pathogenetically more important in leukemogenesis (32). In this study we have analyzed DNA from 26 cases of infant AML to determine if the high incidence of cytogenetic abnormalities of band 11q23 in this disease is due to alterations of $M L L$. Using genomic probes specific for this locus, we observed molecular rearrangements in 15 of 26 cases $(58 \%)$. The rearrangements were clustered within an $\sim 11-\mathrm{kb}$ region of genomic DNA that contains exons 5-13 of $M L L$ (19). In derivative 11 chimeric cDNA species from the $t(4 ; 11), t(9 ; 11)$, and $t(11 ; 19)$ that have been analyzed to date, there is preservation of the open reading frame of this region of the 11q23 gene in each case (17-20,29). A number of previously analyzed breakpoints occurring in the region of exons 6-11 were found to lie between exons $(19,29)$. Therefore, the breaks for cases $1,3,6,7,8$, and 10-13 may similarly lie within intronic DNA. Alternatively, the breaks may occur within exons in this region if the donor and acceptor splice sites are complimentary and maintain the open reading frame in the resulting fusion gene. The breakpoint for case 14 does appear to occur within intronic DNA, in particular the SstI-EcoRI fragment lying between exons 8 and 9 (see Fig. 2). Less is known regarding breakpoints occurring after exon 11 , but it is predicted that breaks in cases $2,4,5,9$, and 15 also maintain the open reading frame of derivative 11 fusion transcripts. It is not clear why cases 4 and 9 do not demonstrate rearrangements in EcoRI digests probed with 4.2E, given the fact that HindIII and BamHI rearrangements map the breakpoints of these cases to the telomeric-most BamHI-EcoRI fragment of Fig. 2. This may be due to comigration of rearranged bands with germline fragments. Another possibility is that deletions of this region have occurred removing certain sequences recognized by $4.2 \mathrm{E}$. Consistent with this are the smaller than expected sizes of HindIII fragments recognized by p98.40 and ps 4 in these cases ( see Table III) and the finding by others that deletions of this locus occur in a significant proportion of cases with 11q23 translocations (33). Of note, the rearrangements identified in this study occurred within the same region where we have previously observed clustered molecular rearrangements of $M L L$ in $70 \%$ of 30 infant ALL cases, all but one of which showed the ALL-associated $t(4 ; 11)(\mathrm{q} 21 ; \mathrm{q} 23)(21)$. These findings, taken together, provide strong evidence that $M L L$ is altered in a high percentage of infant acute leukemia cases.

We identified rearrangements of $M L L$ in all cases with cytogenetic evidence of $11 \mathrm{q} 23$ abnormalities. Cytogenetic alterations in these cases included a $t(9 ; 11)(\mathrm{p} 22 ; \mathrm{q} 23)$, $\mathrm{t}(10 ; 11)(\mathrm{p} 13 ; \mathrm{q} 23), \mathrm{t}(11 ; 17)(\mathrm{q} 23 ; \mathrm{q} 25), \mathrm{t}(11 ; 19)(\mathrm{q} 23 ; \mathrm{p} 13)$, 
Table III. Sizes of Rearranged Fragments after Southern Blot Analysis of Infant AML Cases Using Genomic Probes for MLL

\begin{tabular}{|c|c|c|c|c|c|c|c|c|c|c|}
\hline & \multirow[b]{2}{*}{ Patient } & \multicolumn{3}{|c|}{ HindIII } & \multicolumn{3}{|c|}{ EcoRI } & \multicolumn{3}{|c|}{ BamHI } \\
\hline & & p98 & ps 4 & 4.2E & p98 & ps 4 & $4.2 \mathrm{E}$ & p98 & ps4 & 4.2E \\
\hline \multirow{15}{*}{$\begin{array}{l}\text { Molecular } \\
\text { rearrangement } \\
\text { of } 11 \mathrm{q} 23\end{array}$} & 1 & 8.5 & 12.5 & 12.5 & 7.4 & G & G & $\mathbf{G}$ & 12.5 & 12.5 \\
\hline & 2 & G & G & 3.0 & $G$ & G & 2.7 & $\mathbf{G}$ & G & 12.0 \\
\hline & 3 & 5.0 & G & G & 9.0 & G & $\mathrm{G}$ & $\mathrm{G}$ & $>16$ & $>16$ \\
\hline & 4 & 9.5 & 9.5 & 12.5 & $G$ & $\mathrm{G}$ & G & $G$ & $G$ & 7.5 \\
\hline & 5 & G & G & 7.2 & $G$ & G & $\mathrm{G}$ & $\mathrm{G}$ & G & 7.5 \\
\hline & 6 & 6.4 & 8.7 & 8.7 & $\mathrm{G}$ & 12.5 & $\mathrm{G}$ & $\mathrm{G}$ & 8.8 & 8.8 \\
\hline & 7 & 4.0 & 11.8 & 11.8 & 3.0 & G & G & $\mathrm{G}$ & 8.2 & G \\
\hline & 8 & G & 12.0 & 12.0 & 5.3 & G & $\mathrm{G}$ & $G$ & 11.5 & 11.5 \\
\hline & 9 & 10.0 & 10.0 & 9.0 & $\mathrm{G}$ & G & $\mathrm{G}$ & $\mathrm{G}$ & G & 5.6 \\
\hline & 10 & 12.5 & 8.5 & 8.5 & $\mathrm{G}$ & 8.0 & $\mathrm{G}$ & $\mathrm{G}$ & 12.0 & G \\
\hline & 11 & 8.5 & 7.2 & 7.2 & $\mathrm{G}$ & 6.4 & G & $\mathrm{G}$ & 7.5 & 7.5 \\
\hline & 12 & 12.0 & 12.5 & 12.5 & $\mathrm{G}$ & 4.0 & $\mathrm{G}$ & $\mathrm{G}$ & 12.0 & 12.0 \\
\hline & 13 & 5.0 & 12.5 & 12.5 & 7.2 & $G$ & $\mathrm{G}$ & $G$ & 12.5 & $\mathrm{G}$ \\
\hline & 14 & 14 & 14 & 6.4 & $\mathrm{G}$ & 5.5 & $\mathrm{G}$ & $G$ & 4.5 & 4.0 \\
\hline & 15 & 15 & 15 & 11.5 & $\mathrm{G}$ & G & 6.0 & $\mathbf{G}$ & G & 10.0 \\
\hline \multirow[t]{11}{*}{ Germline 11q23 } & $16^{*}$ & $\mathrm{G}$ & $\mathrm{G}$ & ND & G & $\mathrm{G}$ & G & ND & ND & ND \\
\hline & 17 & $\mathrm{G}$ & $\mathrm{G}$ & G & G & G & G & G & G & $\mathrm{G}$ \\
\hline & 18 & G & G & G & G & G & G & $\mathbf{G}$ & G & G \\
\hline & 19 & G & G & G & G & G & G & G & G & $\mathrm{G}$ \\
\hline & 20 & G & $\mathrm{G}$ & G & G & G & G & G & G & $\mathrm{G}$ \\
\hline & $21^{*}$ & G & G & ND & G & G & G & ND & ND & ND \\
\hline & 22 & G & G & G & G & G & G & G & G & $\mathrm{G}$ \\
\hline & 23 & $\mathrm{G}$ & $\mathrm{G}$ & G & $G$ & G & G & ND & ND & ND \\
\hline & 24 & G & $\mathrm{G}$ & G & G & $G$ & $G$ & ND & ND & ND \\
\hline & 25 & G & G & G & G & $G$ & G & ND & ND & ND \\
\hline & 26 & $\mathrm{G}$ & G & G & $\mathrm{G}$ & G & G & ND & ND & ND \\
\hline
\end{tabular}

$\mathrm{G}$, germline by molecular analysis; ND, not determined. ${ }^{*}$ Cases 16 and 21 were both negative for rearrangement at $11 \mathrm{q} 23$ when analyzed by pulse-field gel electrophoresis of BssHII-digested DNA using p98.40 and ps4 probes.

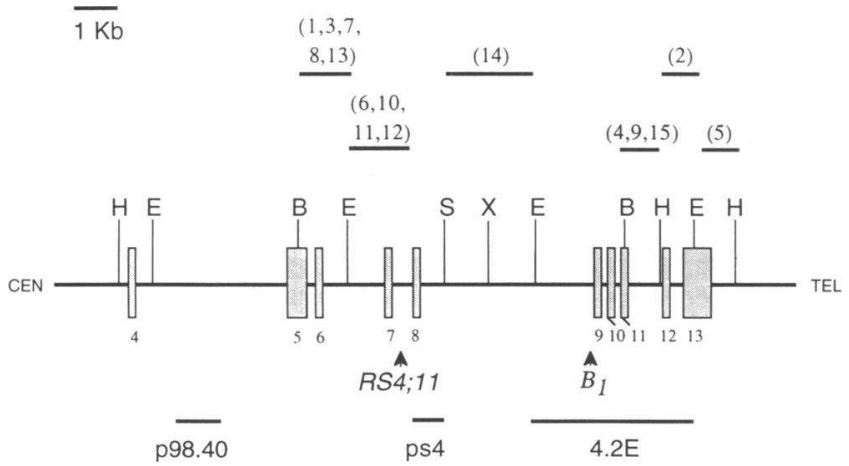

Figure 2. Mapping of rearrangements of $M L L$ in infant AML. The central bar shows a partial restriction map of $M L L$. Vertical bars represent restriction enzyme cleavage sites ( $H$, HindIII; $E$, EcoRI; $B$, BamHI; $S$, SstI). The positions of exons 4-13 (19) are indicated by shaded boxes with numbers. Horizontal bars above the map show positions of $M L L$ rearrangements in infant AML cases, with case numbers (see Table I) indicated in parentheses above each bar. Breakpoints of the RS4;11 and $B_{1}$ ALL cell lines are indicated by vertical arrows. The positions of the $\mathrm{p} 98.40$, ps4, and $4.2 \mathrm{E}$ probes are shown as horizontal bars below the map. $C E N$, centromere; $T E L$, telomere. and a del(11)(q23), each of which has been previously described in childhood AML $(7,8)$. Therefore, involvement of this gene appears to be common to a diverse group of cytogenetic alterations of chromosome band 11q23 in infant AML. Overall, concordance between cytogenetic and molecular 11 q23 findings was observed in $13(76 \%)$ of the 17 cases with adequate cytogenetic analyses. Additionally, however, molecular rearrangements were observed in four cases (nos. $6,7,10$, and 15) lacking detectable cytogenetic alterations of 11q23. In fact, the high incidence of molecular genetic alterations of 11 q23 described here for infant AML is greater than that predicted by several cytogenetic studies of this disease, in which $20-45 \%$ of infants with AML showed cytogenetic abnormalities of band $11 \mathrm{q} 23(2,3,6)$. This increased sensitivity of molecular analysis may be explained by the presence of submicroscopic alterations involving $M L L$ detected only at the molecular level. The utility of using molecular analysis of the $11 \mathrm{q} 23$ region is particularly important in infant acute leukemia given the relative difficulty in obtaining adequate bone marrow samples from these patients for cytogenetic studies and the low mitotic index often observed in infant leukemic marrow specimens. Given the high incidence of molecular rearrangements of $M L L$ observed in this study and the relative ease of perform- 


\begin{tabular}{|c|c|c|}
\hline & Patient & Cytogenetic analysis \\
\hline \multirow{15}{*}{$\begin{array}{l}\text { Molecular } \\
\text { rearrangement } \\
\text { of } 11 \mathrm{q} 23\end{array}$} & 1 & 46,XY,add(5)(q22),der(11)del(11)(p13)add(11)(q23)[7]/46,XY[1] \\
\hline & 2 & $46, \mathrm{XX}, \mathrm{t}(11 ; 19)(\mathrm{q} 23 ; \mathrm{p} 13.1)[20]$ \\
\hline & 3 & Not available \\
\hline & 4 & Not available \\
\hline & 5 & $46, \mathrm{XX}, \mathrm{t}(7 ; 11)(\mathrm{p} 22 ; \mathrm{q} 23)[26] / 46, \mathrm{XX}[5]$ \\
\hline & 6 & $46, \mathrm{XX}, \mathrm{t}(9 ; 11)(\mathrm{p} 22 ; \mathrm{q} 13)[20]$ \\
\hline & 7 & $47, \mathrm{XX},+6, \operatorname{del}(11)(\mathrm{q} 21), \operatorname{add}(22)(\mathrm{q} 13)[15]$ \\
\hline & 8 & $46, X X, t(11 ; 17)(q 23 ; q 25)[14]$ \\
\hline & 9 & $46, X Y, t(10 ; 11)(p 13 ; q 23)[17] / 46, X Y[4]$ \\
\hline & 10 & $\begin{array}{l}\text { 46,XX,der(吕)t( } ; ; 11)(\mathrm{q} 14 ; \mathrm{p} 15), \operatorname{der}(11) \mathrm{t}(\underline{5} ; 11)(\mathrm{q} 31 ; \mathrm{p} 15), \operatorname{der}(22) \operatorname{dirins}(22 ; \underline{5}) \\
\quad(\mathrm{q} 12 ; \mathrm{q} 14 \mathrm{q} 31)[15]\end{array}$ \\
\hline & 11 & Not available \\
\hline & 12 & $47, \mathrm{XY},+21 \mathrm{c}, \mathrm{t}(9 ; 11)(\mathrm{p} 22 ; \mathrm{q} 23)[14] / 47, \mathrm{XY},+21 \mathrm{c} .[6]$ \\
\hline & 13 & Inadequate study \\
\hline & 14 & $46, X Y, \operatorname{del}(11)(q 23)[9] / 46, X Y[6]$ \\
\hline & 15 & $46, X Y[24]$ \\
\hline \multirow[t]{11}{*}{ Germline $11 \mathrm{q} 23$} & 16 & Not available \\
\hline & 17 & $46, X Y, t(4 ; 6 ; 9)(q 31 ; q 25 ; q 34)[14] / 46, X Y[6]$ \\
\hline & 18 & Not available \\
\hline & 19 & Not available \\
\hline & 20 & $46, X Y[20]$ \\
\hline & 21 & Not available \\
\hline & 22 & Not available \\
\hline & 23 & $49, X Y,+8,+21,+22[5] / 46, X Y[20]$ \\
\hline & 24 & $46, \mathrm{XX}[15]$ \\
\hline & 25 & $45, X Y,-7[16] / 46, X Y[4]$ \\
\hline & 26 & $46, \mathrm{XX}, \mathrm{t}(7 ; 11)(\mathrm{q} 11.2 ; \mathrm{p} 15.5), \mathrm{t}(11 ; 12)(\mathrm{q} 13 ; \mathrm{p} 13.2)[14] / 46, \mathrm{XX}[6]$ \\
\hline
\end{tabular}

ing Southern analysis on limited samples, as described here, we recommend that molecular analysis of this gene locus be performed in addition to cytogenetics in the diagnostic work-up of infant AML cases.

It has been demonstrated previously that many acute leukemias with monocytic or myelomonocytic morphology show cytogenetic evidence of 1 lq23 abnormalities $(34,35)$. This, along with the fact that $t(4 ; 11)$ ALL cases often show biphenotypic features with coexpression of both lymphoid and myelomonocytic antigens $(36,37)$, suggests that the affected 1 lq23 gene may be involved in expression of the monocytic phenotype. To further examine this hypothesis we attempted to correlate rearrangements of $M L L$ with morphological subtypes in infant AML. Our results demonstrate a strong correlation between molecular rearrangements of this gene and myelomonocytic (M4) or monocytic (M5) phenotype in infant AML. Of rearranged cases, $93 \%(14 / 15)$ were diagnosed as M4 or M5 compared with only 1 of 11 nonrearranged cases. Moreover, 93\% of cases with an M4 or M5 designation showed molecular alterations of $M L L$, whereas only 1 of $15 \mathrm{M} 4$ or M5 cases was germline at this locus in our studies. In addition, all rearranged cases analyzed expressed the CD15 antigen (which is associated with M4/M5 morphology) while only occasional cases germline at $11 \mathrm{q} 23$ expressed this marker. These results suggest that $M L L$ may be directly involved in monocytic differentiation and its activation by genetic alteration may lead to development of a monocytic or myelomonocytic phenotype in the tumor cells. This is corroborated by studies of secondary AML developing in children treated for ALL with the DNA topoisomerase II inhibitors etoposide and teniposide, both in the epipodophyllotoxin family of chemotherapeutic agents (38). These studies show a high incidence of cytogenetic abnormalities of $11 \mathrm{q} 23$ in therapy-related AML (9-11) and, more recently, rearrangements of the $M L L$ gene in these leukemias (39). Moreover, there appears to be a strong correlation between 11 q23 abnormalities and an M4 or M5 phenotype in the secondary leukemias $(9-11)$. The trithorax gene product of drosophila is characterized by zinc finger DNA binding domains and functions as a transcriptional regulator of homeotic genes involved in the control of segmentation and embryogenesis in the fly $(17,18)$. Therefore, if the 11 q23 gene has similar functions in humans it may control transcriptional activation of homeotic genes involved in hemopoietic differentiation, including expression of the monocytic phenotype. Loss of normal regulation by genetic alterations of this gene in infant acute leukemia may lead to alteration of control of replication and differentiation in monocytic precursor cells. Similarly, in $t(4 ; 11)$ ALL of pre-B cell origin, malignant transformation may have occurred in a B cell progenitor with alteration and consequent deregulation of $M L L$ leading to expression of monocytic or myelomonocytic markers along with lymphoid markers in these leukemias.

M4/M5 morphology and the presence of hyperleukocytosis have both been correlated with a poor prognosis in AML occur- 
ring in infants, and these parameters remain among the few known prognostic indicators in childhood AML (40-42). Our studies of infant AML identified statistically significant correlations between $M L L$ gene rearrangements and either M4/M5 phenotype or hyperleukocytosis. These data therefore provide preliminary evidence that molecular alterations of $M L L$ in infant AML may correlate with a poor prognosis in this disease. It will be extremely important to directly evaluate the prognostic significance of molecular alterations of this gene in infant AML and these studies are currently underway. These findings further emphasize the need to include molecular analysis of the $M L L$ gene in the diagnostic work-up of infant AML.

Our studies demonstrate that molecular rearrangements of $M L L$ are common in infant AML and that molecular analysis of this gene appears to be more sensitive than cytogenetic evaluation for the detection of $11 \mathrm{q} 23$ abnormalities in some patients with this disease. The correlation of both M4/M5 phenotype and hyperleukocytosis with rearrangements of $M L L$ indicates that this genetic alteration may be associated with a poor prognosis in infant AML. Furthermore, the high frequency of these rearrangements in M4 and M5 subtypes suggests that the presence of an altered version of this gene may result in abnormal control of proliferation and differentiation in precursor cells of the monocytic lineage. It is hoped that detailed analysis of $M L L$ in infant AML will reveal fundamental insights into the leukemogenic process in this disease.

\section{Acknowledgments}

We thank Drs. Bill Woods, Jae-Won Lee, and Leslie Robison for helpful discussions. We also thank the following physicians for providing clinical information on study cases: W. Bekele, M.D. ( Beth Israel Medical Center, Newark, NJ); P. Breitfeld, M.D. (Indiana University, Indianapolis, IN); P. C. Davis, M.D. (Medical College of Georgia, Augusta, GA); S. Ferg, M.D. (UCLA, Los Angeles, CA); J. S. Goh, M.D. (Allan Blair Memorial Clinic, Regina, Saskatchewan); P. Grong, M.D. (Long Beach Memorial Hospital, Long Beach, CA); F. S. Hodder, M.D. (Childrens Hospital of Orange County, Orange, CA ); H. J. Johnstone, M.D. (University of Illinois College of Medicine at Chicago, Chicago, IL); J. Kelleher, M.D. (Baystate Medical Center, Springfield, MA); F. Reynolds, M.D. (Fred Hutchinson Cancer Research Center [FHCRC], Seattle, WA); H. Suarez, M.D. (Loyola University, Maywood, IL); and R. Yanofsky, M.D. (Manitoba Cancer Foundation, Winnepeg, Manitoba). We appreciate the efforts of the following cytogeneticists who contributed adequate cases to this study: D. C. Arthur, M.D. (University of Minnesota, Minneapolis, MN); R. G. Best, Ph.D. (University of South Carolina, Columbia, SC); M. G. Butler, M.D. Ph.D. (Vanderbilt University, Nashville, TN); N. A. Heerema, Ph.D. (Indiana University, Indianapolis, IN); R. Higgins, Ph.D. (Children's Mercy Hospital, Kansas City, MO); M. M. Lebeau, Ph.D. (University of Chicago, Chicago, IL): T. Norwood, M.D., and E. Bryant, Ph.D. (Children's Hospital Medical Center, Seattle, WA); K. N. Rosenbaum, M.D. (Children's Hospital National Medical Center, Washington DC); C. J. Sandlin, M.D. (Memorial Medical Center of Long Beach, Long Beach, CA); K. L. Satya-Prakash, Ph.D. (Medical College of Georgia, Augusta, GA); R. Sparkes, M.D. (UCLA Medical Center, Los Angeles, CA); and G. Williams, M.D., Ph.D. (Manitoba Cancer Foundation, Winnepeg, Manitoba).

This research was supported in part by grants from the National Institutes of Health to Childrens Cancer Group (CA-13539) and the Howard Hughes Medical Institute. Poul H. B. Sorensen is the recipient of a Medical Research Council of Canada Centennial Fellowship. J. H. Kersey is a recipient of an outstanding investigator grant (CA-49721) from the National Cancer Institute.

\section{References}

1. Isaacs, H. 1991. Tumours of the Newborn and Infant. Mosby-Year Book, Inc., St. Louis. 67-81.

2. Pui, C-H., S. C. Raimondi, S. B. Murphy, R. C. Ribeiro, D. K. Kalwinsky, G. V. Dahl, W. M. Crist, and D. L. Williams. 1987. An analysis of leukemic cell chromosomal features in infants. Blood. 69:1289-1293.

3. Koller, U., O. A. Haas, W-D Ludwig, C. R. Bartram, J. Harbott, R. PanzerGrumayer, T. Hansen-Hagge, J. Ritter, U. Creutzig, W. Knapp, and H. Gadner. 1989. Phenotypic and genotypic heterogeneity in infant acute leukemia. II. Acute nonlymphoblastic leukemia. Leukemia. 3:708-714.

4. Pui, C-H., D. K. Kalwinsky, M. J. Schell, C. A. Mason, J. Mirro, and G. V. Dahl. 1988. Acute nonlymphoblastic leukemia in infants: clinical presentation and outcome. J. Clin. Oncol. 6:1008-1013.

5. Van Wering, E. R., and W. A. Kamps. 1986. Acute leukemia in infants: a unique pattern of acute non-lymphocytic leukemia. Am. J. Pediatr. Hematol. Oncol. 8:220-224.

6. Kaneko, Y., T. Shikano, N. Maseki, M. Sakurai, M. Sakurai, T. Takeda, Y. Hiyoshi, J. Mimaya, and T. Fujimoto. 1988. Clinical characteristics of infant acute leukemia with or without 11q23 translocations. Leukemia. 2:672-676.

7. Trent, J. M., Y. Kaneko, and F. Mitelman. 1989. Report of the committee on structural chromosome changes in neoplasia. Cytogenet. Cell Genet. 51:533562.

8. Rowley, J. D., M. O. Diaz, R. Espinosa III, Y. D. Patel, E. Van Melle, S. Ziemin, P. Taillon-Miller, P. Lichter, G. A. Evans, J. H. Kersey, D. C. Ward, P. H. Domer, and M. M. Le Beau. 1990. Mapping chromosome band 11q23 in human acute leukemia with biotinylated probes: identification of 11q23 translocation breakpoints with a yeast artificial chromosome. Proc. Natl. Acad. Sci. USA. 87:9358-9362.

9. Pui, C-H., F. G. Behm, S. C. Raimondi, R. K. Dodge, S. L. George, G. K. Rivera, J. Mirro, Jr., D. K. Kalwinsky, G. V. Dahl, S. B. Murphy, W. M. Crist, and D. L. Williams. 1989. Secondary acute myeloid leukemia in children treated for acute lymphoid leukemia. N. Engl. J. Med. 321:136-142.

10. Rubin, C. M., D. C. Arthur, W. G. Woods, B. J. Lange, P. C. Nowell, J. D. Rowley, J. Nachman, B. Bostrom, E. S. Baum, C. R. Suarez, N. R. Shah, E. Morgan, H. S. Maurer, S. E. McKenzie, R. A. Larson, and M. M. LeBeau. 1991. Therapy-related myelodysplastic syndrome and acute myeloid leukemia in children: correlation between chromosomal abnormalities and prior therapy. Blood. 78:2982-2988

11. Pui, C-H, R. C. Ribeiro, M. L. Hancock, G. K. Rivera, W. E. Evans, S. C. Raimondi, D. R. Head, F. G. Behm, M. H. Mahmoud, J. T. Sandlund, and W. M. Crist. 1991. Acute myeloid leukemia in children treated with epipodophyllotoxins for acute lymphoblastic leukemia. N. Engl. J. Med. 325:1682-1687.

12. Chen, C-S., P. S. Medberry, D. C. Arthur, and J. H. Kersey. 1991. Breakpoint clustering in $\mathrm{t}(4 ; 11)(\mathrm{q} 21 ; \mathrm{q} 23)$ acute leukemia. Blood. 78:2498-2504.

13. Ziemin-Van Der Poel, S., N. R. McCabe, H. J. Gill, R. Espinosa III, Y. Patel, A. Harden, P. Rubinelli, S. D. Smith, M. M. LeBeau, J. D. Rowley, and M. O. Diaz. 1991. Identification of a gene, MLL, that spans the breakpoint in 1 lq23 translocations associated with human leukemias. Proc. Natl. Acad. Sci. USA. 88:10735-10739.

14. Cimino, G., D. T. Moir, O. Canaani, K. Williams, W. M. Crist, S. Katzar, L. Cannizzarol, B. Lange, P. C. Nowell, C. M. Croce, and E. Canaani. 1991. Cloning of ALL-1, the locus involved in leukemias with the $t(4 ; 11)(q 21 ; q 23)$, $\mathrm{t}(9 ; 11)(\mathrm{p} 22 ; \mathrm{q} 23)$, and $\mathrm{t}(11 ; 19)(\mathrm{q} 23 ; \mathrm{p} 13)$ chromosome translocations. Cancer Res. 51:6712-6714.

15. Akao, Y., M. Seto, T. Takahashi, M. Saito, K. R. Utsimi, S. Nakazawa, and R. Ueda. 1991. Rearrangements on chromosome 11q23 in hematopoietic tumor-associated $\mathrm{t}(11 ; 14)$ and $\mathrm{t}(11 ; 19)$ translocations. Cancer Res. 51:67086711 .

16. Cimino, G., T. Nakamura, Y. Gu, O. Canaani, R. Prasad, W. M. Crist, A. J. Carroll, M. Baer, C. D. Bloomfield, P. C. Nowell, C. M. Croce, and E. Canaani. 1992. An altered 11-kilobase transcript in leukemic cell lines with the $\mathrm{t}(4 ; 11)(\mathrm{q} 21 ; \mathrm{q} 23)$ chromosome translocation. Cancer Res. 52:3811-3813.

17. Djabali, M., L. Selleri, P. Parry, M. Bower, B. D. Young, and G. A. Evans. 1992. A trithorax-like gene is interrupted by chromosome 11 q23 translocations in acute leukaemias. Nature Genetics. 2:113-118.

18. Tkachuk, D. C., S. Kohler, and M. L. Cleary. 1992. Involvement of a homolog of Drosophila trithorax by $11 \mathrm{q} 23$ chromosomal translocations in acute leukemias. Cell. 71:691-700.

19. Gu, Y., T. Nakamura, H. Alder, R. Prasad, O. Canaani, G. Cimino, C. M. Croce, and E. Canaani. 1992. The $t(4 ; 11)$ chromosome translocation of human acute leukemias fuses the ALL-1 gene, related to Drosophila trithorax, to the AF-4 gene. Cell. 71:701-708.

20. Nakamura, T., H. Alder, Y. Gu, R. Prasad, O. Canaani, N. Kamada, R. P. Gale, B. Lange, W. M. Crist, P. C. Nowell, C. M. Croce, and E. Canaani. 1993. Genes on chromosomes 4,9 , and 19 involves in $11 \mathrm{q} 23$ abnormalities in acute leukemia share sequence homology and/or common motifs. Proc. Natl. Acad. Sci. USA. 90:4631-4635. 
21. Chen, C-S., P. H. B. Sorensen, P. H. Domer, G. H. Reaman, S. J. Korsmeyer, N. A. Heerema, G. D. Hammond, and J. H. Kersey. 1993. Molecular rearrangements on chromosome $11 \mathrm{q} 23$ predominate in infant acute lymphoblastic leukemia and are associated with specific biologic variables and poor outcome. Blood. 81:2386-2393.

22. Lampkin, B., R. Wells, W. Woods, F. Ruymann, L. Odorn, D. Benjamin, I. Bernstein, D. Belcher, C. Versteeg, J. Buckley, S. Feig, T. Kim, W. Smithson, A Srivastava, R. Tannous, K. Whitt, L. Wolff, M. Krailo, and D. Hammond. 1990 Preliminary results: transplantation (BMT) vs intensification chemotherapy (Itf) and maintenance chemotherapy (M) vs no $\mathbf{M}$ in childhood acute non-lymphocytic leukemia (ANL). Proc. Am. Soc. Clin. Oncol. Annu. Meet. 9:219. (Abstr.)

23. Woods, W. G., B. J. Lange, N. Kobrinsky, J. Buckley, S. Neudorf, J. Sanders, L. Miller, D. Bernard, D. Benjamin, J. DeSwarte, D. Kalousek, D. Shina, and D. Hammond. 1991. Intensively timed induction therapy followed by autologous (auto) or allogeneic (allo) bone marrow transplantation (BMT) for children with acute myeloid leukemia (AML) or myelodysplastic syndrome (MDS): a CCSG pilot study. Proc. Am. Soc. Clin. Oncol. Annu. Meet. 10:234. (Abstr.)

24. Smith, F. O., B. C. Lampkin, C. Versteeg, D. A. Flowers, P. A. Dinndorf, J. D. Buckley, W. G. Woods, G. D. Hammond, and I. D. Bernstein. 1992. Expression of lymphoid-associated cell surface antigens by childhood acute myeloid leukemia cells lacks prognostic significance. Blood. 79:2415-2422.

25. Stong, R. C., S. J. Korsmeyer, J. L. Parkin, D. C. Arthur, and J. H. Kersey. 1985. Human acute leukemia cell line with the $t(4 ; 11)$ chromosomal rearrangement exhibits B lineage and monocytic characteristics. Blood. 65:21-31.

26. Cohen, A., T. Grunberger, W. Vanek, E. D. Dube, P. J. Doherty, M. Letarte, C. Roifman, and M. H. Freedman. Constitutive expression and role in growth regulation of interleukin-1 and multiple cytokine receptors in a biphenotypic leukemic cell line. Blood. 78:94-102.

27. Greisinger, F., J. M. Greenberg, and J. H. Kersey. 1989. T cell receptor gamma and delta rearrangements in hematologic malignancies: relationship to lymphoid differentiation. J. Clin. Invest. 84:506-516.

28. ISCN. 1991. Guidelines for Cancer Cytogenetics, Supplement to An International System for Human Cytogenetic Nomenclature. F. Mitelman, editor. Karger, Basel. 54 pp.

29. Domer, P. H., S. S. Fakharzadeh, C-S. Chen, J. Jockel, L. Johansen, G. A. Silverman, J. H. Kersey, and S. J. Korsmeyer. 1993. Acute mixed-lineage leukemia $\mathrm{t}(4 ; 11)(\mathrm{q} 21 ; \mathrm{q} 23)$ generates an MLL-AF-4 fusion product. Proc. Natl. Acad. Sci. USA. 90:7884-7888.

30. Hanson, C. A., and J. H. Kersey. 1988. A modified method of DNA extraction from peripheral blood and bone marrow specimens. Am. J. Hematol. 28:176-180.

31. Feinberg, A. P., and B. Vogelstein. 1983. A technique for radiolabeling DNA restriction endonuclease fragments to high specific activity. Anal. Biochem. 132:6-10.

32. Rowley, J. D. 1992. The der( 11 ) chromosome contains the critical breakpoint junction in the $4 ; 11,9 ; 11$, and $11 ; 19$ translocations in acute leukemia. Genes Chromosomes Cancer. 5:262-264.

33. Thirman, M. J., H. J. Hill, R. C. Burnett, D. Mbangkollo, N. R. McCabe, H. Kobayashi, M. O. Diaz, and J. D. Rowley. 1992. A cDNA probe detects all rearrangements of the $M L L$ gene in leukemias with common and rare 11q23 translocations. Blood. 80(Suppl. 1):254a. (Abstr.)

34. Raimondi, S. C., D. K. Kalwinsky, Y. Hayashi, F. G. Behm, J. Mirro, Jr., and D. L. Williams. 1989. Cytogenetics of childhood acute nonlymphocytic leukemia. Cancer Genet. Cytogenet. 40:13-27.

35. Bitter, M. A., M. M. LeBeau, J. D. Rowley, R. A. Larson, H. M. Golomb, and J. W. Vardiman. 1987. Associations between morphology, karyotype, and clinical features in myeloid leukemias. Hum. Pathol. 18:211-225.

36. J. L. Parkin, D. C. Arthur, C. S. Abramson, R. W. McKenna, J. H. Kersey, R. I. Heideman, and R. D. Brunning. 1982. Acute leukemia associated with the $t(4 ; 11)$ chromosome rearrangement: ultrastructural and immunologic characteristics. Blood. 60:1321-1331.

37. Stong, R. C., and J. H. Kersey. 1985. In vitro culture of leukemic cells in $t(4 ; 11)$ acute leukemia. Blood. 66:439-443.

38. Schneider, E., Hsiang, Y-H., and L. F. Liu. 1990. DNA topoisemerases as anticancer drug targets. Adv. Pharmacol. 21:149-183.

39. Hunger, S. P., D. C. Tkachuk, M. D. Amylon, M. P. Link, A. J. Carroll, J. L. Welborn, C. L. Wilman, and M. L. Cleary. 1993. HRX involvement in de novo and secondary leukemias with diverse chromosome 11 q23 abnormalities. Blood. 81:3197-3203.

40. Grier, H. E., R. D. Gelber, B. M. Camitta, M. J. Delorey, M. P. Link, K. N. Price, P. R. Leavitt, and H. J. Weinstein. 1987. Prognostic factors in childhood acute myelogenous leukemia. J. Clin. Oncol. 5:1026.

41. Buckley, J. D., R. L. Chard, R. L. Baehner, M. E. Nesbit, B. C. Lampkin, W. G. Woods, and G. D. Hammond. 1988. Improvement in outcome for children with acute nonlymphocytic leukemia. Cancer (Phila.). 63:1457.

42. Chessells, J. M., U. O'Callaghan, and R. M. Hardisty. 1986. Acute myeloid leukemia I. Childhood: clinical features and prognosis. Br. J. Haematol. 63:555-564. 